\title{
The Nodoconchiinae, a new subfamily of Cytheridae (Crustacea, Ostracoda)
}

\author{
Daiane Ceolin $^{1 *}$, Robin Whatley ${ }^{2}$, Gerson Fauth $^{1}$ \& Andrea Concheyro ${ }^{3}$ \\ ${ }^{1}$ Instituto Tecnológico de Micropaleontologia - itt Fossil, Universidade do Vale do Rio dos Sinos-UNISINOS, Avenida \\ Unisinos, 950, CEP 93022-000, São Leopoldo-RS, Brazil \\ ${ }^{2}$ Micropalaeontology Research Group, Institute of Earth Sciences, Aberystwyth University, Aberystwyth, Cardiganshire \\ SY23 3DB, UK \\ ${ }^{3}$ IDEAN - Instituto de Estudios Andinos ‘Don Pablo Groeber', Consejo Nacional de Investigaciones Científicas y \\ Técnicas, Facultad de Ciencias Exactas y Naturales, Universidad de Buenos Aires, Pabellón II, Ciudad Universitaria, CP \\ 1428 Buenos Aires, Argentina \\ *Correspondence: daianeceolin@yahoo.com.br
}

\begin{abstract}
The new subfamily Nodoconchiinae of the Cytheridae Baird is erected to accommodate three genera: Austrocythere Hartmann, 1989a, Nodoconcha Hartmann, 1989 a and Ectonodoconcha gen. nov.. Austrocythere seems to be known only from the type species $A$. reticulotuberculata Hartmann, from its type locality in the Recent Antarctic and from the Antarctic Oligocene. Nodoconcha, however, apart from its original record by Hartmann from the Antarctic as Nodoconcha minuta, has also been encountered in the Oligocene of the Antarctic. In the present study, we have identified seven species of Nodoconcha from the Maastrichtian and Danian of the Neuquén Basin, together with a new genus from the Danian, Ectonodoconcha lepidotus gen. et sp. nov.. The new species of Nodoconcha are N. polytorosa sp. nov., N. sanniosis sp. nov. and N. upsilon sp. nov., and Nodoconcha? sp. that is the possible ancestor of the entire group. Previously described species now placed in the genus are: N. paleocenica (Bertels, 1973), N. jaguelensis (Bertels, 1974) and Nodoconcha sp. (Bertels, 1974). The Nodoconcha species are divided into the Minuta and Upsilon groups.
\end{abstract}

Keywords: Ostracoda; Cytheridae; Nodoconchiinae; evolution; Maastrichtian-Danian; Neuquén Basin

Received 28 January 2015; accepted 20 August 2015

Hartmann (1989a) described two new genera, Austrocythere and Nodoconcha from the Oligocene and Recent. These genera were encountered in extremely cold conditions in the Antarctic. Hartmann classified Austrocythere as Cytheridae (Cytheride? sp. 1987; Austrocythere reticulotuberculata Hartmann 1989a). He found it in South Georgia, Lavoisier Island and Adelaide Island, at depths between $116 \mathrm{~m}$ and $215 \mathrm{~m}$. The type locality of Austrocythere is South Georgia.

Although Hartmann (1997) classified Austrocythere as family Cytheridae on the basis of both hard and soft parts, he classified Nodoconcha incertae sedis. However, the present authors believe that, because of its great similarity to Austrocythere, Nodoconcha is a member of the same family and subfamily. This is indeed suggested by Hartmann in his earlier works as listed in synonymy of Nodoconcha (see below).We have consulted a number of colleagues who all consider Nodoconcha to be Cytheridae.

There have been some subsequent records of Austrocythere reticulotuberculata Hartmann from the Recent of Lützow Holm Bay, East Antarctic (Yasuhara et al. 2007), Admiralty Bay, King George Island, West Antarctica (Majewski \& Olempska 2005) and Oligocene CRP-2/2A and CRP-3 Drill holes, Victoria Land Basin, Antarctic (Dingle \& Majoran 2001). On the other hand, Nodoconcha has been recorded by various authors as early as the Oligocene (Lower Miocene of New Zealand, Milhau 1993; Victoria Land Basin, Antarctica, Dingle 2000; and King George, Antarctic, Blaszyk 1987).

The genus Nodoconcha was classified by Hartmann (1997) incertae sedis, although every indication from his early work is that it belongs to the Cytheridae. The type species Nodoconcha minuta Hartmann, 1989a has been recorded from the Antarctic Peninsula, South Georgia, South Orkneys, Lavoisier Island, Hope
Bay and Adelaide Island, between 185-370 m depth (Hartmann 1988, 1989a, b, 1990) and Ross Island (Briggs 1978).

In the present study the antiquity of the occurrence of Nodoconcha is confirmed and extended into the Danian and Maastrichtian. The new occurrence of seven species of Nodoconcha in the Neuquén Basin, well known for its rich fossil content, represents a place of species cluster and migration route for many species (Whatley \& Ballent 1996; Ballent \& Whatley 2006, 2007; Piovesan et al. 2012; Ceolin et al. 2015).

The three genera Nodoconcha, Austrocythere and Ectonodoconcha gen. nov. are grouped together as a distinct subfamilial entity within the family Cytheridae Baird. We base our suprageneric assignations on both soft and hard part characteristics in respect of the first two genera by Hartmann $(1988,1989 a, b, 1990)$ and the obvious close relationship between Austrocythere and Nodoconcha. Although Ectonodoconcha is only known fossil and from closed carapaces, it is included within the new subfamily on grounds of putative carapace similarities with Nodoconcha and Austrocythere.

The Cytheridae (all other Cytheridae genera) are a somewhat heterogeneous group and do not bear the characteristic carapace components (see diagnosis below) of the Nodoconchiinae. They themselves are currently in need of a serious taxonomic review. However, Dr Mark Warne, probably the ostracod worker with most knowledge of the Cytherinae, considers that Cythere O. F. Müller, Loxocythere (Loxocythere) Warne, Microcytherura and Tetracytherura Ruggieri (possibly a junior synonym of Microcytherura) are certainly members of the Cytherinae, but none of these genera resembles any of the three genera we include in the Nodoconchiinae.

The aim of this paper is to present new species of Nodoconcha belonging to our new subfamily Nodoconchiinae, some previously 


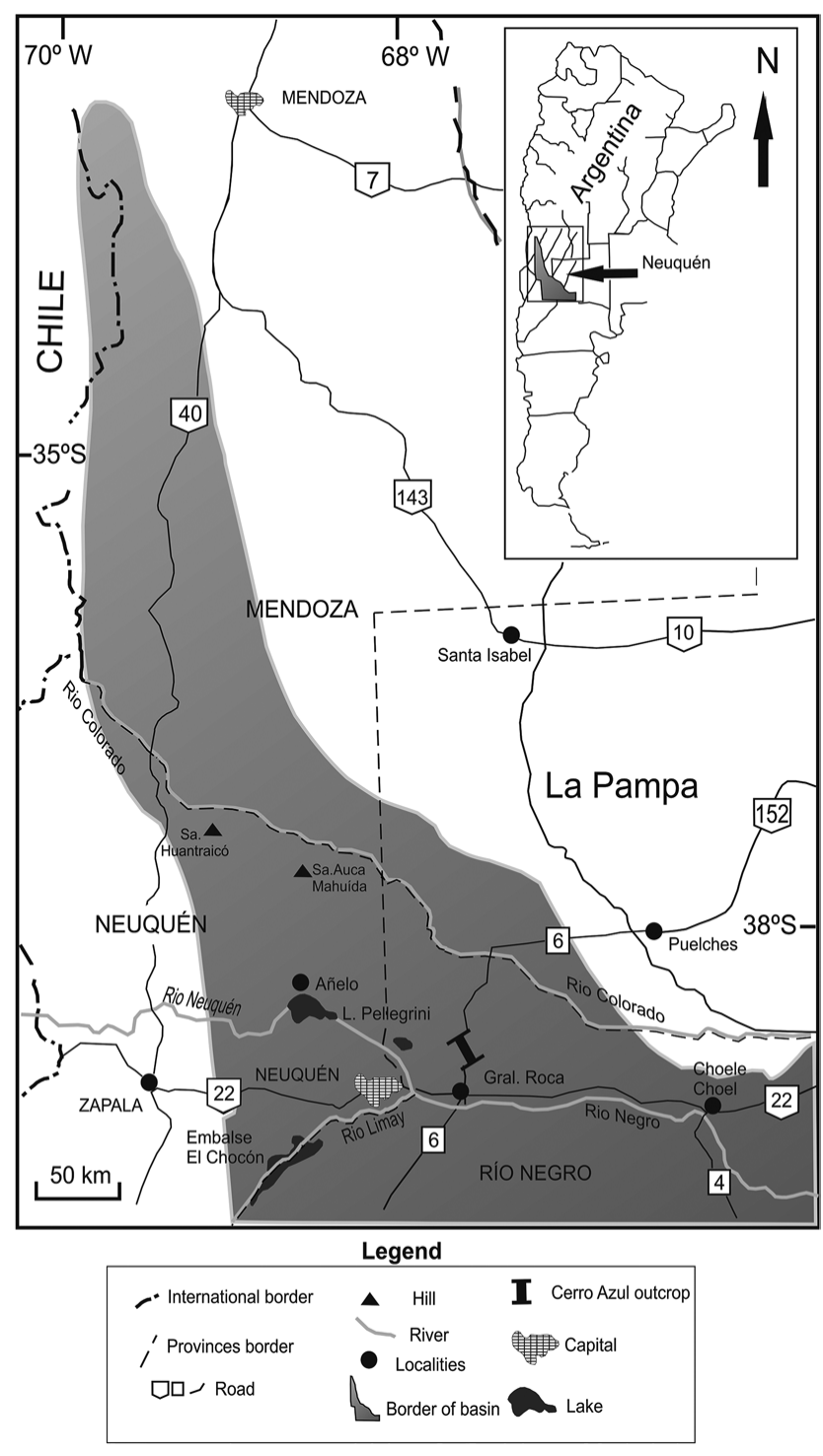

Fig. 1. The Neuquén Basin showing the location of the Cerro Azul section (modified from Del Río et al. 2011).

identified as 'Cytherura?' and 'Wolburgia' by Bertels (1973, 1974) and to demonstrate possible evolutionary trends and relationships with the Recent species of this genus.

\section{Geological setting}

The Neuquén Basin is located in west-central Argentina between latitudes $32^{\circ} \mathrm{S}$ and $40^{\circ} \mathrm{S}$. It is developed in the provinces of Mendoza, Neuquén, Río Negro and La Pampa. In latitude $35^{\circ} \mathrm{S}$, the basin extends to form the Neuquén embayment that comprises $600 \mathrm{~km}$ of extension in a north-south direction and $300-400 \mathrm{~km}$ east-west. It has a maximum thickness of $7000 \mathrm{~m}$ of marine and non-marine sedimentary rocks, ranging from the late Jurassic to the Paleocene (Concheyro et al. 2002; Howell et al. 2007; AguirreUrreta et al. 2011; Fig. 1 herein).

The marine sediments from the Cerro Azul section ( $38^{\circ} 50^{\prime} 48^{\prime \prime}$ $\mathrm{S}, 67^{\circ} 52^{\prime} 20^{\prime \prime} \mathrm{W}$ ), a relatively new site for micropaleontological studies in the eastern sector of Lake Pellegrini, Neuquén Basin, were deposited during the first transgression from the Atlantic Ocean in the Late Maastrichtian-Lower Danian (Jagüel Formation) and Danian (Roca Formation). The samples are composed of calcareous siltstones and claystones and, according to Musso et al. (2012), the samples from the Jagüel Formation have a homogeneous lithology of grey calcareous mudstone. An alternation of carbonate rocks and greenish-grey calcareous mudstones characterize the Roca Formation and the base of the Jagüel Formation was defined, according to criteria adopted by Uliana \& Dellapé (1981), by the first appearance of organogenic limestone. The age of the samples was determined by calcareous nannofossils (Musso et al. 2012; Fig. 2).

\section{Material and methods}

Twenty-seven samples were studied, seven from the Maastrichtian and 20 from the Danian, from the Cerro Azul section. Approximately $20 \mathrm{~g}$ of dried rock was crushed and soaked in $200 \mathrm{ml}$ of a $35 \%$ hydrogen peroxide solution for 24 hours. Residues were then washed and divided into grain fractions 63, 180 and $250 \mu \mathrm{m}$ and dried at $60^{\circ} \mathrm{C}$. All ostracods were hand-picked under a stereo-microscope from each size fraction. Selected specimens were photographed using an EVO MA15 Zeiss scanning electron microscope.

\section{Systematic descriptions}

The suprageneric classification adopted is that proposed by Moore \& Pitrat (1961) with some modifications. In the systematic descriptions, the following conventions are employed: L, length; $\mathrm{H}$, height; W, width, RV, right valve, LV, left valve, CMS, central muscle scars. All dimensions are in millimetres. Size, based on length, is as follows: very small $(<0.400 \mathrm{~mm})$; small $(0.410$ $0.500 \mathrm{~mm})$; medium $(0.510-0.700 \mathrm{~mm})$; large $(0.710-0.900 \mathrm{~mm})$; very large $(>0.900 \mathrm{~mm})$. Type and figured specimens are deposited in the collections of the Facultad de Ciencias Exactas y Naturales, Laboratorio de Micropaleontología, Buenos Aires, Argentina, under their respective catalogue numbers LM-FCEN 3210-3231; $3540-3541$.

\section{Subfamily Nodoconchiinae subfam. nov. Ceolin \& Whatley}

This group forms a distinct entity within the family Cytheridae. In their ornamentation and carapace organization, they are quite different from other Cytheridae.

The Cytherinae - those members of the family not in Nodoconchiinae subfam. nov., such as Cythere O. F. Müller and Loxocythere Hornibrook - are a group of ovate, subovate, often ventrolaterally tumid genera, which usually do not bear tubercles, nor strong sulcae and there is an essential similarity about them in carapace morphology and ornamentation. It would be very difficult to accommodate the taxa we include in the Nodoconchiinae with the other members of the Cytheridae. We have consulted the World Ostracoda Database (Brandão 2015) but find that in the section on the Cytheridae (as defined above), the database authors include genera that we would include in other well-established families and it is evident that this family in the database is in need of a modern review. Therefore, we feel justified in erecting the new subfamily Nodoconchiinae and including within it the genera Austrocythere Hartmann, Nodoconcha Hartmann and Ectonodoconcha gen. nov..

This new subfamily first appears in the Maastrichtian and ranges through to the Recent in the form of Austrocythere and Nodoconcha.

Class Ostracoda Latreille, 1806 Order Podocopida, Müller, 1894 Suborder Podocopina Sars, 1866 Family Cytheridae Baird, 1850 Subfamily Nodoconchiinae new subfamily

Diagnosis. Cytheridae with subovate/subrectangular to subrhomboidal carapaces in lateral view and subelliptical, parallel-sided with constricted but flared end margins in dorsal view. Anterior 


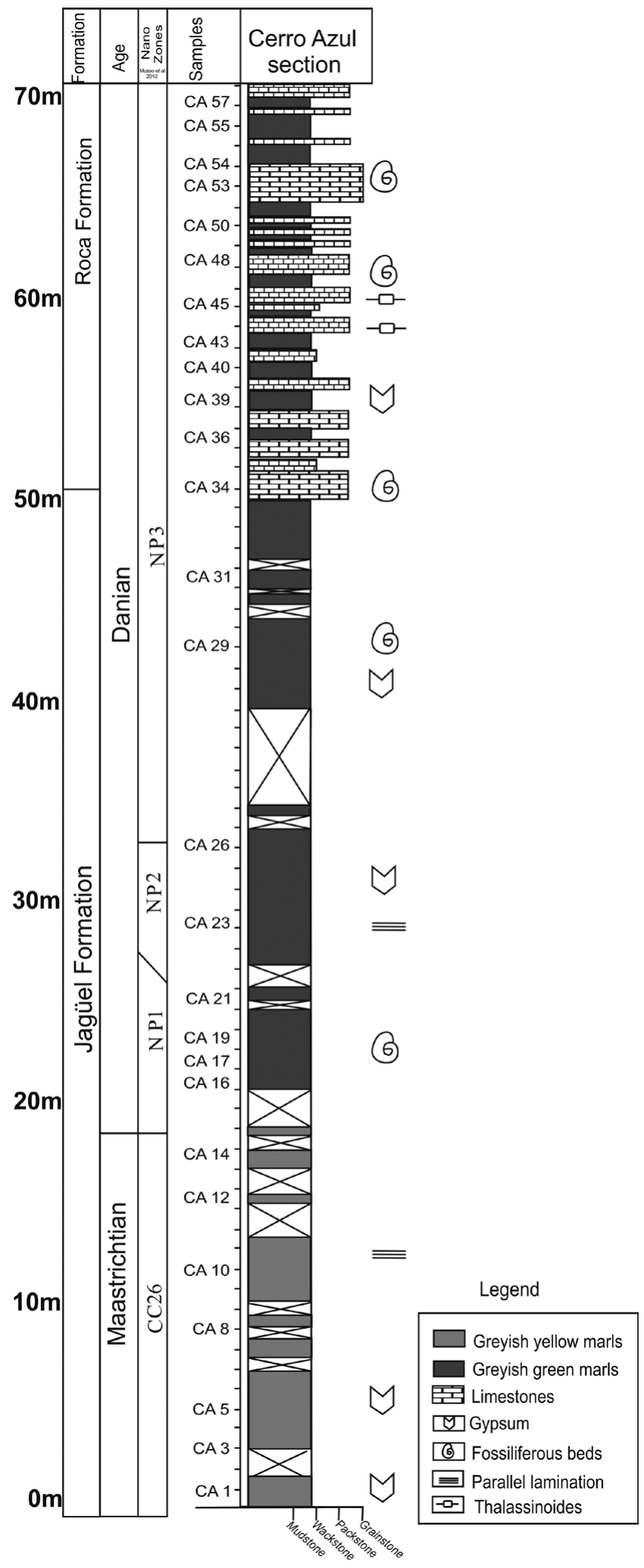

Fig. 2. Cerro Azul profile with sample positions (modified from Musso et al. 2012).

margin well rounded; posterior margin bluntly pointed with apex at or near mid-height. Dorsal margin straight; ventral margin biconvex about an oral concavity of variable depth. Marginal rim ranging from poorly to strongly developed. Surface ornament tuberculate, reticulate and costate, these elements interacting to various degrees between species. Most species have two prominent dorsal-dorsolateral tubercles separated by a median sulcus and, ventrolaterally, a concave rib bearing three tubercles. Hinge modified antimerodont with a long straight, crenulated median element and rather small terminal sockets in the LV bearing small locules, CMS four similar adductors in a straight row with a single oval to heart-shaped antennal scar.

Remarks. The Minuta Group comprise all those species that in their overall carapace morphology and particularly their carapace ornament resemble variations on that of Nodoconcha minuta Hartmann. This, therefore, comprises most of the species of Nodoconcha: N. minuta, N. polytorosa sp. nov., N. sanniosis sp. nov. and Nodoconcha. sp. (Bertels, 1974).

\section{Genus Nodoconcha Hartmann, 1989a}

Type species. Nodoconcha minuta Hartmann, 1989a

\author{
Minuta group \\ Nodoconcha minuta Hartmann, $1989 a$ \\ (Pl. 1, fig. 1)
}

1978 'Roundstonia' sp. Briggs: 29, figs 2-12.

1988 Cytheride? Hartmann: 149, pl. 1, fig. 8.

1989 a Nodoconcha minuta gen. et sp. nov. Hartmann: 218-219,

figs $42-49 \mathrm{~b}$.

1989b Nodoconcha minuta Hartmann; Hartmann: 251.

1990 Nodoconcha minuta Hartmann; Hartmann: 211-121, figs

70-71; pl. 7, figs 63-65.

2000 Nodoconcha minuta Hartmann; Dingle: 489, fig. f.

2001 Nodoconcha aff. N. minuta Hartmann; Dingle \& Majoran: 375.

2007 Nodoconcha minuta Hartmann; Yasuhara et al.: 486, fig. 9.

Description. A medium to large species of the genus Nodoconcha of the Nodoconchiinae, subovate in lateral view. Anterior margin well rounded and extending below ventral margin; posterior margin with apex above mid-height with a long keel-like posteroventral slope. Dorsal margin straight, overhung ocularly, medianly and posteromedianly by valve ornament. Ventral margin biconvex about a distinct oral incurvature, in the centre of which internally is a circular snap-knob. Ornament of tubercles, sulci and reticulation. There is a small eye tubercle, behind which is a large tubercle behind mid-length on the dorsal margin and projecting beyond it is another, smaller tubercle. These two latter tubercles are separated by a distinct, diagonally inclined median sulcus. Between these two tubercles and close to the dorsal margin, there are two small circular tubercles en echelon, while a further two small tubercles occur posterior to the posteromedian tubercle. Three tubercles, all of the same size, and approximately the same size as the posteromedian tubercle, occur on a ventrolateral rib in a shallowly concave-upwards curve. The summits of all five major tubercles bear a very fine reticulation within the larger reticulation that covers the entire valve surface, except the extreme end margins, and much of that reticulation is itself secondarily reticulate, but not as finely as on the summit of the tubercles. Hinge modified antimerodont with, in the RV, the anterior terminal element being a dentate bar with three large teeth and one small proximal tooth; while the posterior terminal element bears five teeth; the median element is a finely locellate groove. CMS not seen. Inner lamella vestibulate at each end with a well-developed selvage anteriorly.

Remarks. Dingle \& Majoran (2001) recorded N. aff. N. minuta Hartmann from the Oligocene of the Antarctic, but neither described nor illustrated it. We are, therefore, unable to compare it with $N$. minuta Hartmann nor any of the species of the Minuta group. However, we believe it belongs to $N$. minuta. 


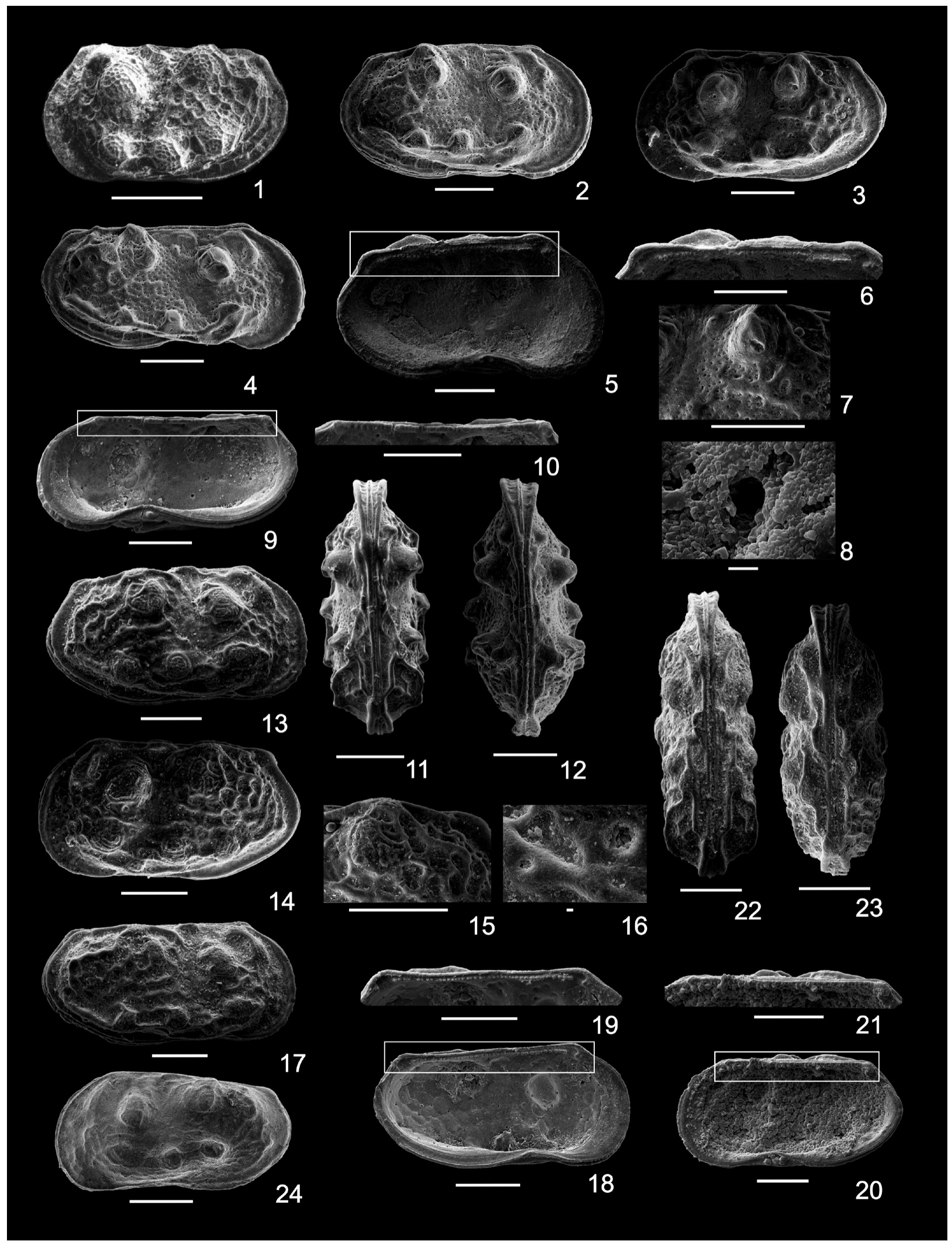

Explanation of Plate 1. Scale bars are $100 \mu \mathrm{m}$, except those in figures 8 and 16, which are $2 \mu \mathrm{m}$. fig. 1. Nodoconcha minuta Hartmann, 1989a, valve, left view (illustration from Hartmann 1990, pl. VII, fig. 63, Hope Bay). figs 2-12. Nodoconcha polytorosa sp. nov.: 2, holotype LM-FCEN 3210, carapace, female, right view; 3,7-8, paratype LM-FCEN 3211, 3, carapace, female, left view; 7, detail of ornament; 8, detail of simple pore; 4, paratype LM-FCEN 3212, carapace, male, right view; 5-6, paratype LM-FCEN 3213, 5, female, left valve, internal view; 6, detail of the hinge; 9-10, paratype LM-FCEN 3541, 9, male, right valve, internal view; 10, detail of the hinge; 11, paratype LM-FCEN 3214, dorsal view, male; 12, holotype LM-FCEN 3210, dorsal view, female. figs 13-23. Nodoconcha sanniosis sp. nov.: 13, holotype LM-FCEN 3215, carapace, right view, female; 14, paratype LM-FCEN 3216, female, carapace, left view; 15-16, paratype LM-FCEN 3218, 15, detail of mask-like reticulation, 16, detail of sieve-type pore; 17, paratype LM-FCEN 3217, carapace, male, right view; 18-19, paratype LM-FCEN 3218, 18, left valve, male, internal view; 19, detail of the hinge; 20-21, paratype LM-FCEN 33540, right valve, internal view; 21, detail of the hinge; 22, paratype LM-FCEN 3217, carapace, male, dorsal view; 23, paratype LM-FCEN 3219, carapace, female, dorsal view. fig. 24. Nodoconcha sp. (Bertels, 1974), LM-FCEN 706, carapace, left view. 


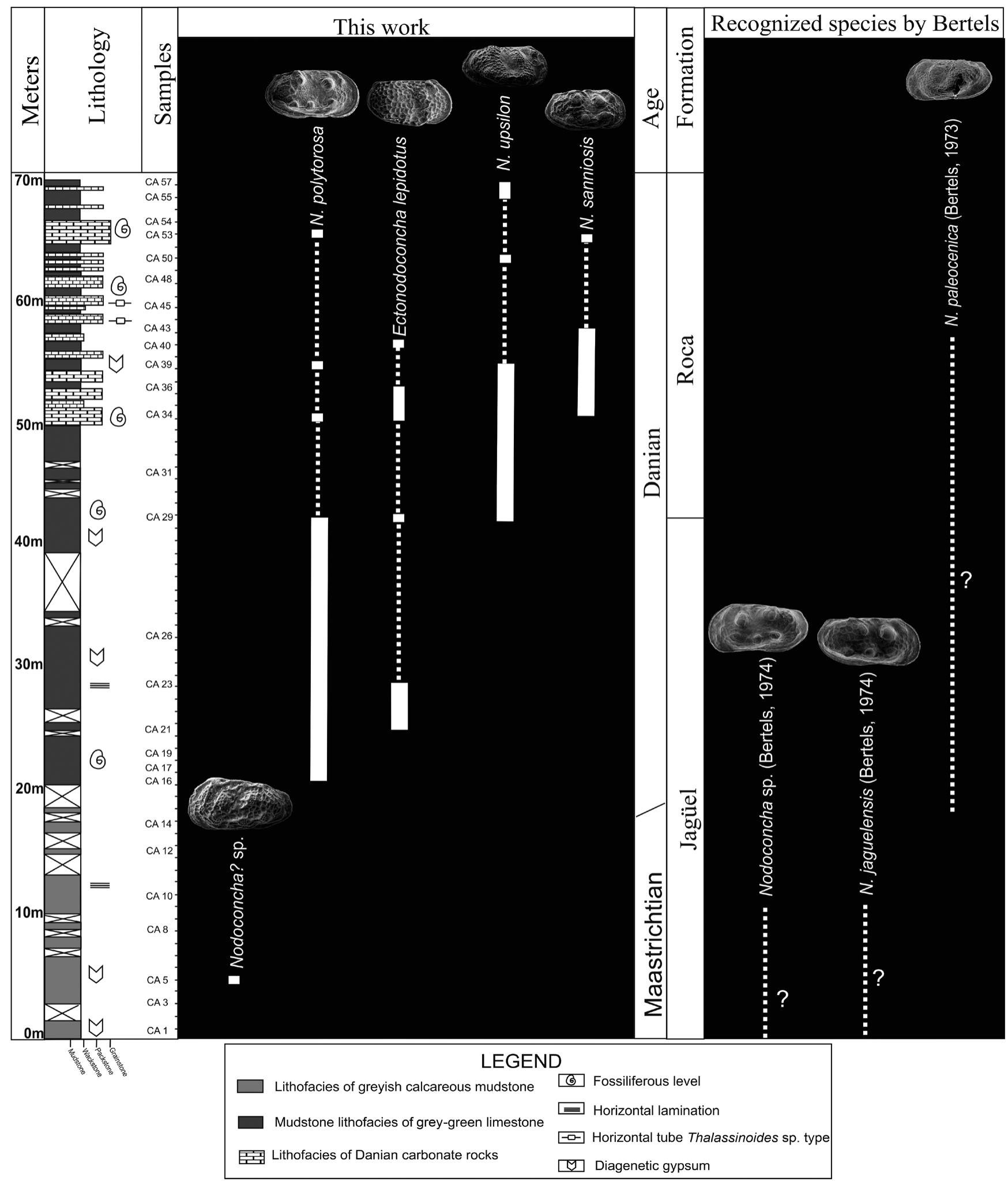

Fig. 3. Stratigraphical distribution of Nodoconcha species and Ectonodoconcha gen. nov.. Dashed lines in the diagram on the right-hand side represent the distribution reported by Bertels of species not occurring in the Cerro Azul Section. Solid lines represent actual distribution ranges.

Nodoconcha polytorosa sp. nov. Ceolin \& Whatley (Pl. 1, figs 2-12)

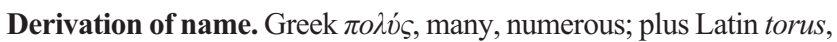
elevation, protuberance, 'many tubercles' referring to the numerous rounded tubercles that occur on the carapace of this species.

Diagnosis. A small species of Nodoconcha characterized by a ventrolateral rib on which three small tubercles are disposed longitudinally and a double posteromedian rib on the dorsal margin. An anterior marginal ridge extends from the anterior cardinal angle to an anteroventral position. Surface of the carapace strongly punctate and reticulate in part.

Holotype. One complete female carapace, LM-FCEN 3210 .

Paratypes. LM-FCEN 3211-3214, 3541. 
Material. 47 specimens from samples 16, 17, 19, 21, 23, 26, 29, 34, 39 and 53. Danian.

Description. Subrectangular in lateral view with rounded end margins. In dorsal view, subovate with compressed extremities, mainly anteriorly, which is somewhat flared. Shell of medium thickness. Anterior margin broadly rounded, more narrowly below mid-height. Posterior more narrowly rounded with apex above mid-height. Dorsal margin straight but overhung in posterior part by a tubercle. Ventral margin biconvex about an anterocentral oral concavity and obscured in lateral view by valve tumidity, more prominent in males, in which posteroventral keel is better developed. Dorsal cardinal angles pronounced, especially anteriorly. LV larger than RV with some overlap anteroventrally and from the mid-posterior to posteroventral region of the valve. Greatest length at mid-height; greatest height at both anterior cardinal angles; greatest width in posterior one-third. Ornament reticulopunctate, more pronounced in anterior and posterior areas. A pronounced, mainly smooth marginal rim extends peripherally around the free and dorsal margins. There is a distinct ventrolateral rib, which bears three longitudinally disposed tubercles. This rib divides into two with the lower rib overhanging the ventral surface and terminating anteroventrally. An irregular, sinuous rib extends from the eye tubercle adjacent to the dorsal rim, to a posterodorsal complex. Two tubercles occur anterodorsally and posterodorsally. A distinct subvertical median sulcus extends ventrally to the ventrolateral rib. A smaller, post-ocular sinus separates the eye-tubercle from the anterodorsal tubercle. Apart from some smooth ribs and the marginal rim, the carapace is covered by small puncta, which also occur on the flanks and summits of some tubercles. The reticulation is more or less confined to the anterior and posterior and it is not preferentially oriented. Normal pore canals are simple, most on the elevation of muri or the tubercles. Large, simple pore conuli occur across the valve, especially posteriorly. Hinge modified antimerodont. In the LV, the anterior terminal element is a biloculate socket in which the two locules are disposed obliquely, with the proximal one above the distal. The entire socket is buttressed by an anti-slip structure ventrally. The posterior terminal element is a curved, loculate socket with six smaller loculae. The median element is a long, strongly denticulate bar with numerous relatively long circular denticles. Calcified inner lamella very wide posteroventrally; avestibulate. Radial pore canals not seen and CMS imperfectly seen. The position of the larger tubercles are reflected internally. Sexual dimorphism with males more elongate and less inflated at posterior one-third than females.

\section{Dimensions.}

\begin{tabular}{|c|c|c|c|c|c|c|c|}
\hline & & & & $\mathrm{L}$ & $\mathrm{H}$ & W & Sample \\
\hline Holotype & $\begin{array}{c}\text { LM-FCEN } \\
3210\end{array}$ & q & carapace & 0.462 & 0.240 & 0.213 & 23 \\
\hline Paratype & $\begin{array}{c}\text { LM-FCEN } \\
3211\end{array}$ & q & carapace & 0.424 & 0.227 & 0.201 & 17 \\
\hline Paratype & $\begin{array}{c}\text { LM-FCEN } \\
3212\end{array}$ & 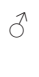 & carapace & 0.585 & 0.235 & 0.192 & 23 \\
\hline Paratype & $\begin{array}{c}\text { LM-FCEN } \\
3213\end{array}$ & q & valve & 0.490 & 0.272 & & 17 \\
\hline Paratype & $\begin{array}{c}\text { LM-FCEN } \\
3214\end{array}$ & $\hat{\sigma}$ & carapace & 0.434 & 0.211 & 0.187 & 21 \\
\hline Paratype & $\begin{array}{c}\text { LM-FCEN } \\
3541\end{array}$ & $\pi$ & valve & 0.443 & 0.199 & & 21 \\
\hline
\end{tabular}

Stratigraphical range. Danian of Cerro Azul, General Roca.

Remarks. Differs from Nodoconcha minuta Hartmann in being slightly smaller, in possessing, as well as a median sulcus, a post-ocular sulcus and in its ornament, which is much more punctate than $N$. minuta. It also has a much better developed marginal rim, particularly anteriorly. A further difference is that in N. polytorosa sp. nov. the posteromedian tubercle is a double structure, unlike the single structure of $N$. minuta.

\section{Nodoconcha sanniosis sp. nov. Ceolin \& Whatley} (Pl. 1, figs 13-23)

Derivation of name. Latin sanniosis 'one who makes faces'. With reference to the rather face-like appearance of the ornamentation on the surface of the lateral tubercles.

Diagnosis. A small species of Nodoconcha characterized by a group of five tubercles, three of which are disposed ventrolaterally and whose ornament is mask-like. Surface reticulopunctate.

Holotype. One complete female carapace, LM-FCEN 3215.

Paratypes. LM-FCEN 3216-3219.

Material. 43 specimens from samples 34, 36, 39, 40 and 53. Danian.

Description. Small, subrectangular in lateral view. Subovate in dorsal view. Shell of medium width. Anterior margin broadly rounded with apex at mid-height. Anteroventrally there are small, blunt, rounded, marginal denticles. Posterior margin bluntly pointed with apex at mid-height. Dorsal margin straight but overhung in posterior part by ornament. Ventral margin biconvex about shallow anterocentral oral concavity and not obscured by valve tumidity. LV overlaps the RV, mainly on posterior and ventral margins. Dorsal cardinal angles distinct. Ornamentation reticulotuberculate. The reticulum posteriorly is extremely coarse due to the fact that most of the muri have been enlarged into strong ribs that are chaotically disordered across the ventral surface. Except anterodorsally, there are relatively few interconnecting muri so that over most of the area there are no reticular cells. The muri, especially posteriorly, bear simple pores on small conuli. Anteriorly, the muri are less strong and there is a genuine reticulum where much larger conuli and perforations occur distally. There are five large tubercles on the carapace surface plus an eye tubercle. The two largest tubercles on the dorsolateral surface have flanks that are ornate with a distinct reticulation pattern in a group of three mask-like structures on each tubercle. These are separated from each other by a vertical median sulcus, the anterior-most tubercle is separated by the post-ocular sinus from a strongly buttressed eye tubercle. Three smaller tubercles occur in a line posteroventrally, the largest being anterior. Each tubercle is surrounded dorsally by an inverted ' $U$ '-shaped rib and centrally comprises several short, horizontal striae. From the eye tubercle, a sinuous rib extends closely parallel to the dorsal rib on to a posterodorsal complex above the posterodorsal tubercle and, from this complex, a strong mural rib extends ventrally and eventually joins the ventrolateral rib. A strong, smooth marginal rim surrounds the entire valve margin. Rare sieve-type pores are present mainly in the anterior region. Greatest length near mid-height; greatest height in posterior third. Hinge modified antimerodont, with median element in LV a long, strongly denticulate bar with numerous relatively strong circular denticles. Calcified inner lamella very wide posteroventrally; avestibulate. Radial pore canals not seen. CMS with four adductors in a vertical line and a single oval frontal scar. The positions of the larger tubercles are reflected internally. Sexual dimorphism pronounced with males more elongate and less inflated than females. 
Dimensions.

\begin{tabular}{|c|c|c|c|c|c|c|c|}
\hline & & & & $\mathrm{L}$ & $\mathrm{H}$ & W & Sample \\
\hline Holotype & $\begin{array}{c}\text { LM-FCEN } \\
3215\end{array}$ & ㅇ & carapace & 0.462 & 0.240 & 0.212 & 34 \\
\hline Paratype & $\begin{array}{c}\text { LM-FCEN } \\
3216\end{array}$ & q & carapace & 0.410 & 0.210 & 0.211 & 34 \\
\hline Paratype & $\begin{array}{c}\text { LM-FCEN } \\
3217\end{array}$ & 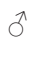 & carapace & 0.502 & 0.243 & 0.170 & 34 \\
\hline Paratype & $\begin{array}{c}\text { LM-FCEN } \\
3218\end{array}$ & q & valve & 0.441 & 0.217 & & 26 \\
\hline Paratype & $\begin{array}{c}\text { LM-FCEN } \\
3219\end{array}$ & $\pi$ & carapace & 0.452 & 0.201 & 0.180 & 34 \\
\hline Paratype & $\begin{array}{c}\text { LM-FCEN } \\
3540\end{array}$ & 우 & valve & 0.470 & 0.236 & & 29 \\
\hline
\end{tabular}

Stratigraphical range. Danian of Cerro Azul, General Roca.

Remarks. This species differs from Nodoconcha polytorosa sp. nov. in the better developed pattern of reticulation and in the absence of a strong ventrolateral rib that joins the three tubercles. It also differs from $N$. minuta in being more elongate and in the pattern of reticulation, in the absence of a strong ventrolateral rib that joins the three tubercles and in being more elongate.

Nodoconcha sp. (Bertels, 1974)

(P1. 1, fig. 24)

1974 Cytherura? sp. Bertels: 392, pl. 2, figs 12 a-b.

Type material. One carapace from Bertels' material, LM-FCEN 706, from Lower Jagüelian Substage (Lower Maastrichtian?), Fortín General Roca. Rio Negro Province. Argentina.

Dimensions. L: 0.429; H: 0.220; W: 0.200.

Diagnosis and remarks. An elongate subrectangular species of Nodoconchiinae typified by reticulotuberculate ornament. Unlike any others species of genus, the chain of the three ventrolateral tubercles extends on to the anterior marginal surface with a further two tubercles. The reticulation is rather irregular and variable. In places there seems to be a micro-ornament between the two tubercles and the reticulation. Marginal rim better developed than in $N$. minuta Hartmann, but much less well developed than in N. polytorosa sp. nov.. However, this is clearly a member of Minuta group.

Nodoconcha jaguelensis (Bertels, 1974)

(Pl. 2, figs 1-2)

1974 Cytherura? jaguelensis Bertels: 392, pl. 2, figs 10a-b, 11.

Type material. Two carapaces and two valves from Bertels' material. Holotype LM-FCEN 703; paratypes LM-FCEN 704 and 705 from lower beds of the upper member of the Jagüel Formation, Fortín General Roca, Rio Negro Province. Argentina. Approximately $67^{\circ} 32^{\prime} \mathrm{W} ; 39^{\circ} 00^{\prime} \mathrm{S}$.

Diagnosis. A very elongate, subrectangular species of Nodoconcha with anterior margin obliquely rounded. Surface reticulotuberculate with the third tubercle on the upper ramus of the ventrolateral rib absent or only feebly developed. Posterodorsal tubercle not well defined. Intertubercular area posterocentrally with horizontal or oblique riblets.

Description. A small, elongate carapace, subrectangular in lateral view, subovate in dorsal view with a well-defined median sulci. Anterior margin well rounded with apex at about mid-height and with dorsal part of anterodorsal slope straight to almost concave. Posterior margin narrow, bluntly pointed with apex at mid-height. On the posterodorsal slope, there is a small concavity while the posteroventral slope is convex. Dorsal margin straight and only slightly overhung mid-posteriorly by small, nodose inflation. Anterior and posterior cardinal angles well defined. Ventral margin biconvex about slight oral concavity. Greatest height at anterocardinal angle, greatest length at mid-height, greatest width at posterior third. Ornamentation reticulotuberculate, with an irregular reticulum that covers the entire surface, except anteriorly. It is very chaotic posterodorsally with a tendency for the muri to be preferentially oriented ventrally, while more medianly, they are orientated laterally. A ventrolateral rib joins three small, poorly defined, horizontally aligned tubercles. A median sulcus disposed almost vertically separates the antero and posterodorsal tubercles. The posterior tubercle is poorly defined. A small, post-ocular sulcus is also developed. Eye tubercle small and close to valve margin and with small ocular rib. Marginal rim rather weakly developed. Other features not seen. Sexual dimorphism present with males more elongate and narrower than females.

Dimensions. Paratype LM-FCEN 704, L: 0.382; H: 0.187; W: 0.157 .

Remarks. Differs from Nodoconcha sanniosis sp. nov. in the absence of an exclusive ornamentation on the tubercles, the absence of reticulation on the anterior margin and less well-defined tubercles, especially the most posterior on the ventrolateral rib. Differs from Nodoconcha polytorosa sp. nov. in its more elongate shape, more developed reticulation pattern and larger nodes, mainly antero- and posterodorsally.

\section{Upsilon group}

Diagnosis. The distinct ' $U$ '-shaped lobe encircling the median sulcus sets all members of this group apart from the Minuta group. They also lack the characteristic ventral and ventrolateral tubercles of members of the Minuta group.

Remarks. The Upsilon group comprises Nodoconcha upsilon, $N$. palaeocenica (Bertels, 1973), Nodoconcha? sp. and Ectonodoconcha.

\section{Nodoconcha upsilon sp. nov. Ceolin \& Whatley}

(Pl. 2, figs 3-9)

Derivation of name. Greek $v \pi \sigma i \lambda o v$, upsilon, with reference to the reclining ' $U$ '-shape of the lobe that surrounds the median sulcus.

Diagnosis. A medium species of Nodoconcha characterized by the reclining ' $U$ '-shaped lobe that surrounds the median sulcus and the fact that the ventrolateral tubercles are not developed. Ornament of irregular reticulation.

Holotype. One complete female carapace, LM-FCEN 3220.

Paratypes. LM-FCEN 3221-3225.

Material. 62 specimens from samples 29, 31, 34, 36, 39, 50, 55 and 57. Danian.

Description. Subrectangular in lateral view with rounded end margins; in dorsal view subovate with compressed extremities, especially anteriorly. Females more inflated in the posterior one-third than males. Moderately thick-shelled. Anterior margin broadly rounded, most narrowly below mid-height. Posterior margin more narrowly rounded with apex above mid-height. Both end margins bear very small marginal denticles on their ventral edges. Dorsal margin straight and overhung only by the posterior dorsal tubercle. Ventral margin biconvex, about an anterocentral oral concavity and not obscured in lateral view. Dorsal cardinal angles 

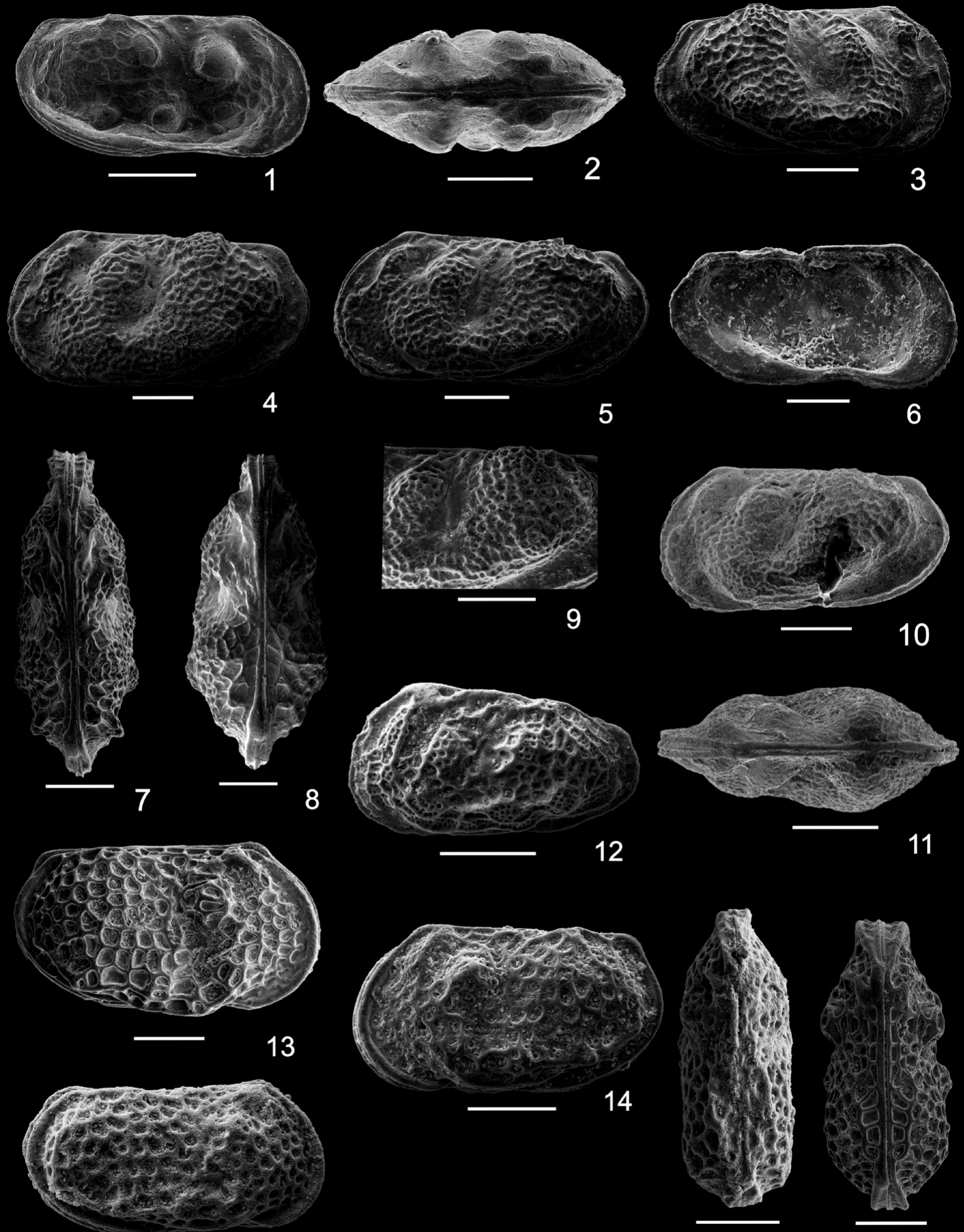

16

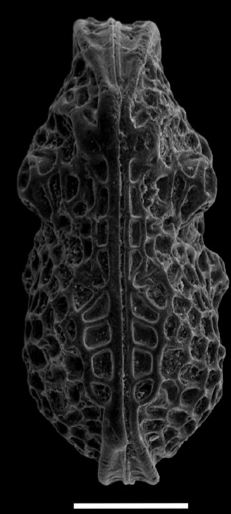

Explanation of Plate 2. Scale bars are $100 \mu \mathrm{m}$. figs 1-2. Nodoconcha jaguelensis (Bertels, 1974): 1, paratype LM-FCEN 704, carapace, female, right view; 2, paratype LM-FCEN 705, female, carapace, dorsal view. figs 3-9. Nodoconcha upsilon sp. nov.: 3, holotype LM-FCEN 3220, carapace, female, right view; 4, 9, paratype LM-FCEN 3221, 4, female, carapace, left view; 9, detail of reticulation; 5, paratype LM-FCEN 3222, male, left view, carapace; 6, paratype LM-FCEN 3223, valve, female, internal view; 7, paratype LM-FCEN 3224, male, carapace, dorsal view; 8, paratype LM-FCEN 3225, female, dorsal view. figs 10-11. Nodoconcha paleocenica (Bertels, 1973): 10, paratype LM-FCEN 516, female, carapace, left view; 11, paratype LM-FCEN 517, female, carapace, dorsal view. fig. 12, Nodoconcha? sp., LM-FCEN 3226, valve, left view. figs 13-17. Ectonodoconcha lepidotus gen. et sp. nov.: 13, holotype LM-FCEN 3227, carapace, female, right view; 14, paratype, LM-FCEN 3228, carapace, female, left view; 15, paratype LMFCEN 3229, carapace, male, right view; 16, paratype LM-FCEN 3230, male, carapace, dorsal view; 17, paratype LM-FCEN 3231, female, carapace, dorsal view. 


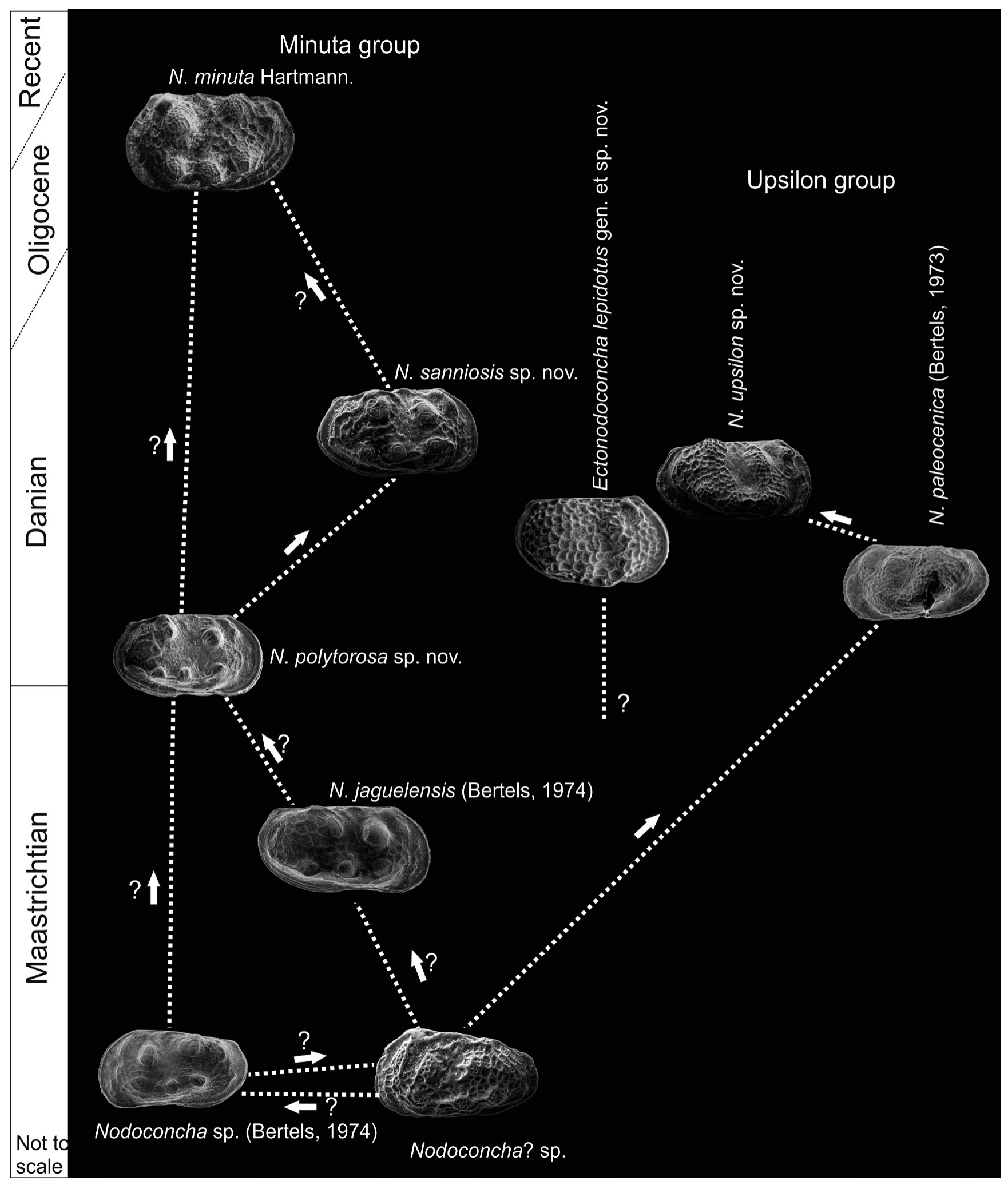

Fig. 4. Evolutionary trends in the new subfamily Nodoconchiinae including Bertels species and based upon external carapace morphology and stratigraphical occurrence.

pronounced, especially posteriorly. LV larger than RV with some overlap posterodorsally and anterodorsally. Greatest length at midheight; greatest height at anterior cardinal angle and in the position of the posterodorsal tubercle; greatest width in posterior one-third. Ornamentat reticulopunctate. There is a distinct oblique median sulcus, the base of which is largely smooth, which terminates just below mid-height. Another, longer oblique postocular sulcus, also largely smooth extends from just behind the small, but prominent, eye tubercle. Anteroventrally, it is bridged by a small elevated area that is reticulated. A large, reclined ' $U$ '-shaped lobe surrounds the median sulcus. It expands posterodorsally into a long, irregular tubercle that overreaches the dorsal margin. Another elongate tubercular area extends anteroventrally from near the eye tubercle, which in some specimens bears a rib from just above mid-height. Some specimens have small tubercles close to the ocular rib. The reticulation is strongly developed and, in most individuals, the 
horizontal muri are strongest, giving rise to small, longitudinal riblets. These are often pronounced on the summits of the larger tubercles. Normal pore canals are of two types: one on the muri that are small, simple and mainly conjunctive, while the other, larger in the solae, are clearly sieve-type. Hinge modified antimerodont. In the LV, the anterior terminal element is a bi-loculate socket in which the two loculae, are disposed obliquely, with the proximal above the distal. The entire socket is buttressed ventrally by an anti-slip structure. The posterior terminal element is a curved, loculate socket with six smaller loculae. The median element is a long, strongly denticulate bar with numerous relatively large circular denticles. In the anterior part of the median element, there are larger denticles than other parts. Calcified inner lamella very wide posteroventrally; anteriorly the inner lamella and line of concrescence are coincident and there is no vestibulum. Radial pore canals not seen. CMS as for family, the anterior scar is ovate. Sexual dimorphism with males more elongate than females.

Dimensions.

\begin{tabular}{|c|c|c|c|c|c|c|c|}
\hline & & & & $\mathrm{L}$ & $\mathrm{H}$ & W & Sample \\
\hline Holotype & $\begin{array}{c}\text { LM-FCEN } \\
3220\end{array}$ & q & carapace & 0.528 & 0.274 & 0.139 & 34 \\
\hline Paratype & $\begin{array}{c}\text { LM-FCEN } \\
3221\end{array}$ & 우 & carapace & 0.461 & 0.227 & 0.137 & 34 \\
\hline Paratype & $\begin{array}{c}\text { LM-FCEN } \\
3222\end{array}$ & 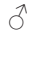 & carapace & 0.540 & 0.258 & 0.125 & 34 \\
\hline Paratype & $\begin{array}{c}\text { LM-FCEN } \\
3223\end{array}$ & 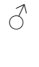 & valve & 0.491 & 0.251 & & 26 \\
\hline Paratype & $\begin{array}{c}\text { LM-FCEN } \\
3224\end{array}$ & 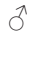 & carapace & 0.515 & 0.152 & 0.198 & 34 \\
\hline Paratype & $\begin{array}{c}\text { LM-FCEN } \\
3225\end{array}$ & q & carapace & 0.589 & 0.251 & 0.275 & 34 \\
\hline
\end{tabular}

Stratigraphical range. Danian of Cerro Azul, General Roca.

Remarks. Bertels' species, Nodoconcha paleocenica (ex. Wolburgia) (1973) from the Danian, differs in lacking the type of reticulation of the present species and the structures paralleling the anterior margin. In addition, the ' $U$ '-shaped elevation surrounding the median sulcus is incomplete in Bertels' species. The two species differ in dorsal view and in details of ornament.

Nodoconcha paleocenica (Bertels, 1973)

(Pl. 2, figs 10-11)

1973 Wolburgia? paleocenica Bertels: 332, pl. 5, figs 12a-b, 13.

Type material. Two carapaces and two valves from Bertels' material. Holotype LM-FCEN 515; paratypes LM-FCEN 516-517 from Roca Formation of Fortín General Roca, Río Negro Province, Argentina.

Description. An elongate subovate species of Nodoconcha with a distinct marginal rim and two strong, lobe-like structures, somewhat resembling certain species of the Palaeozoic Palaeocopida. These two lobes are distinctively rounded dorsally and joined ventrally to form a large ' $U$ '-shaped structure. Both the two lobes and the remainder of the shell surface are distinctly punctate.

Dimensions. Paratypes LM-FCEN 516-517, L: 0.446; H: 0.226; W: 0.175 .

Remarks. This species differs from $N$. upsilon sp. nov., to which group it clearly belongs, by the fact that in $N$. upsilon the ornament is distinctly reticulate while in N. paleocenica (Bertels, 1973) it is punctate. Also in N. upsilon the dorsal terminations of the lobes are not rounded and the post-ocular sulcus is in two distinct parts separated by a ridge. The lower part of this sulcus is absent in $N$. paleocenica. There are also many other differences in the ornament of the two species, such as the divergence into two of the anteromarginal rim in N. upsilon.

\section{Nodoconcha? sp.}

(Pl. 2, fig. 12)

Material. Five poorly preserved specimens from sample 5, Maastrichtian.

Dimensions. LM-FCEN 3226, L: 0.347; H: 0.260.

Description. Elongate subtriangular in lateral view; anterior margin rounded with apex below mid-high. Posterior margin subtruncate with apex at about mid-height. Dorsal margin straight and sloping posteriorly; obscured by sinuous ribs dorsally. Ventral margin with large, shallow oral concavity. There are two large sulci, a median and a post-ocular, both extending forward diagonally. Ornament reticulate with muri around free margins parallel to those margins with short intervening ribs giving rise to numerous, largely circular, but some quadrate reticulae. The bases of all sulci are smooth. A sinuous ventrolateral rib bears distinct swellings and another occurs on the dorsal margin posteromedianly. Internal features not seen.

Remarks. While this species lacks, for example, the three ribs in a curved row ventrolaterally, the site of the ribs exists putatively as does the site of the posteromedian rib. We believe this to be an ancestor of Nodoconcha and we have used that name questionably. It is our intention in the very near future to seek further examples of the species in the Maastrichtian of the Neuquén Basin.

\section{Genus Ectonodoconcha gen. nov. Ceolin \& Whatley}

Type species. Ectonodoconcha lepidotus sp. nov. Ceolin \& Whatley

Derivation of name. Greek $\varepsilon \kappa \tau o$ ecto, without, away; plus Nodoconcha. With reference to the fact that, although related, this species belongs to a genus different from Nodoconcha.

Diagnosis. A genus of the Upsilon group of the Nodoconchiinae subfamily nov. with a strongly developed ventrolateral keel. Subovate to subrectangular in lateral view with a well-rounded, anterior marginal rim, accentuated both anteriorly and posteriorly by a proximal and parallel depression. Posterior margin rather less pointed than other members of the group. Dorsal margin straight, only slightly overhung by lateral ornament in the female and not at all in the male. In dorsal view the male is very laterally compressed and flat-sided, with the female much less so. The female's outline is modified by the median sulcus and the tubercles that flank it. The lateral surface is strongly reticulate and the reticulae (see Pl. 2, fig. 13) are heavily secondarily reticulate. The median sulcus is rather feebly developed and is delineated anteriorly by two poorly developed tubercles. Other tubercles, also feebly developed, occur in a concave row immediately above the delineation of the ventral and lateral surfaces. Males less high and more elongate than females. Eye tubercle with a simple pore.

Remarks. It differs from species of Nodoconcha in lacking large nodes posteroventrally and in its massively strong reticulation. We believe this genus to be an early Danian offshoot of Nodoconcha.

Ectonodoconcha lepidotus sp. nov. Ceolin \& Whatley (Pl. 2, figs 13-17) 
Derivation of name. Greek $\lambda \varepsilon \pi \check{\delta} \delta \omega \tau o ́ \varsigma$ lepidotus; covered in scales. With reference to the fact that in the posterior half of the valve, the reticulae are rather like fish-scales.

Diagnosis. A species of the genus Ectonodoconcha with a smooth, strongly developed ventrolateral keel. Strong ventrolateral rib, becoming almost alate anterior of mid-length. Ornament of extremely strong reticulation with circular, ovate, scale-like and quadrate cells and strong subcentral tubercle, which is also reticulate. Reticulae very like the scales of a carp. Smooth rim around free margins. Eye partially ornamented.

Type material. One complete female carapace, LM-FCEN 3227.

Paratypes. LM-FCEN 3228-3231.

Material. 20 complete carapaces from samples 21, 23, 29, 34, 36 and 40. Danian.

Description. Small, elongate and subrhomboidal in lateral view. In dorsal view, both end margins are splayed due to the angle of the peripheral rims. The alar process is not prominent in this view, although the tubercle immediately below and behind the eye is very prominent. Anterior margin widely and evenly rounded about midheight. Posterior margin more narrowly rounded, asymmetrical with apex above mid-height and very long, gently curved ventral slope. Dorsal margin straight, slightly obscured posteriorly by valve surface. Ventral margin irregularly biconvex with marked oral incurvature, largely obscured by alar process. LV larger than RV with overlap around the entire margin, especially at the dorsal cardinal angles and posteroventrally. Greatest length above mid-height; greatest height medianly; greatest width at one-third posteriorly. Eye tubercle large and over-reaching the dorsal margin. A strong, smooth marginal rim with a small denticle anteriorly, occurs peripherally at both end margins. Ornament of extremely strong reticulae, embracing cells ranging in shape from circular through oval to quadrate and polygonal; and giving an aspect of the scales of such fish as carp, bass or mullet. Small simple pores, mostly conjunctive, occur on the muri and there are small pore conuli elsewhere. Some pore conuli in the solae are apparently sieve-type. The ornament extends on to the alar process and covers an elevated area immediately posteroventral to the eye tubercle. Internal features not seen.

Dimensions.

\begin{tabular}{|c|c|c|c|c|c|c|c|}
\hline & & & & $\mathrm{L}$ & $\mathrm{H}$ & W & Sample \\
\hline Holotype & $\begin{array}{c}\text { LM-FCEN } \\
3227\end{array}$ & q & carapace & 0.453 & 0.253 & 0.175 & 23 \\
\hline Paratype & $\begin{array}{c}\text { LM-FCEN } \\
3228\end{array}$ & o & carapace & 0.369 & 0.200 & 0.125 & 29 \\
\hline Paratype & $\begin{array}{c}\text { LM-FCEN } \\
3229\end{array}$ & $\hat{\sigma}$ & carapace & 0.404 & 0.206 & 0.153 & 36 \\
\hline Paratype & $\begin{array}{c}\text { LM-FCEN } \\
3230\end{array}$ & $\hat{\sigma}$ & carapace & 0.384 & 0.200 & 0.151 & 36 \\
\hline Paratype & $\begin{array}{c}\text { LM-FCEN } \\
3231\end{array}$ & q & carapace & 0.440 & 0.225 & 0.225 & 26 \\
\hline
\end{tabular}

Stratigraphical range. Danian of Cerro Azul, General Roca.

Remarks. Differs from Nodoconcha polytorosa sp. nov. in the absence of ventrolateral and posterodorsal tubercles and in the pattern of the fish-scale like reticulation.

\section{Evolutionary history of the Nodoconchiinae}

The new evidence presented in this paper allows us to demonstrate that this subfamily has a long and varied phylogenetic history dating from the Lower Maastrichtian to the present day.

\section{Austrocythere}

Austrocythere seems to exist only as a single species. A. reticulotuberculata Hartmann, 1989a is from the Oligocene to Recent. All records are from the Antarctic and from cold water (Blaszyk 1987; Dingle \& Majoran 2001).

\section{Nodoconcha}

By contrast with Austrocythere, the genus Nodoconcha is represented by a number (7) of species as well as the type species N. minuta Hartmann (see Fig. 3). The Minuta group which comprises, in stratigraphical order, Nodoconcha sp. (Bertels, 1974), N. polytorosa sp. nov., N. sanniosis sp. nov. and N. minuta Hartmann, represents what seems to be a straight line of evolution within four species (Fig. 4).

Nodoconcha sp. (Bertels, 1974), which overall is somewhat similar to $N$. minuta, ranges from Lower to Upper Maastrichtian within the Jagüel Formation of Neuquén. This seems to give rise to $N$. polytorosa sp. nov., which first appears early in the Danian and extends well into the late Danian, Roca Formation. This, in turn, is thought to be ancestral to $N$. sanniosis sp. nov., which first appears in the Danian, Roca Fm. but does not survive this formation. With respect to $N$. minuta, which first appears in the Oligocene, it is difficult to determine whether it evolved from $N$. sanniosis or $N$. polytorosa. In terms of morphology, either one could be the ancestor. Nodoconcha sp. aff. N. minuta is reported from the Miocene Ross Sea by Dingle (2000). However, since it is neither described nor illustrated, we are unable to comment on its possible status.

Nodoconcha jaguelensis (Bertels, 1974), which has approximately the same Maastrichtian biochron as Nodoconcha sp. (Bertels, 1974), can either be seen as a potential ancestor of the Minuta group, or as a short lived descendant from either that group or a common ancestor. The same can be said of Nodoconcha? sp., in that it could be either the ancestor of Nodoconcha sp. (Bertels, 1974) or a derivative form from a common ancestor. While it lacks many of the biocharacters of the Minuta group, it shares enough, notably the two major sulci and the posterodorsal tubercle, to denote a close relationship.

Two closely related species are N. paleocenica (Bertels, 1973) from the early Danian, Jagüel Formation to the late Danian, Roca Formation and $N$. upsilon sp. nov., with a more restricted biochron within in the middle and upper Danian. The two species are noted for a ' $U$ '-shaped structure in their ornament and constitute the Upsilon group. It is thought that N. paleocenica (Bertels, 1973) may have evolved from Nodoconcha? sp. and N. upsilon sp. nov. from N. paleocenica (Bertels, 1973).

Lastly, a species that we have placed in the subfamily differs sufficiently from Nodoconcha to demand separate generic status. This is Ectonodoconcha lepidotus gen. et sp. nov., a genus that appears early in the Danian and just survives to the upper part of the Danian. Although it evidently derives from Nodoconcha, we are unable to state with any degree of certainty from which of the two groups mentioned above it has evolved.

\section{Conclusions}

The Nodoconchiinae subfam. nov. are a close-knit group of three genera Austrocythere Hartmann, Nodoconcha Hartmann and Ectonodoconcha gen. nov.. They arose in the Maastrichtian where they rapidly diversified, survived the Cretaceous-Tertiary boundary event and continued to proliferate in the Danian. They seem to have declined somewhat in the later Paleocene and are represented today by only two species, Austrocythere reticulotuberculata Hartmann and Nodoconcha minuta Hartmann.

One of the areas of our future work in the Upper CretaceousTertiary strata of Neuquén Basin will be to seek more evidence on 
the early origins of this group, which we presently believe to reside in either of the two species Nodoconcha? sp. or N. jaguelensis (Bertels, 1974).

\section{Acknowledgements and Funding}

This study forms part of the doctoral project of the first author, financially supported by a Padre Milton Valente Scholarship of the Universidade do Vale do Rio dos Sinos - Unisinos. The study was partly undertaken at Aberystwyth University during a doctoral internship of the first author supported by Conselho Nacional de Desenvolvimento Científico e Tecnológico (CAPES - Proc. BEX 2696/14-2). The authors thanks go to Andrea Caraméz from Universidad de Buenos AiresUBA and Telma Musso from Universidad Nacional del Comahue, Neuquén, Argentina, for their help in the field and for some SEM images; to Charlie Benda for help in matters concerning Aberystwyth. During the writing of this paper we have been very grateful for valuable advice and information from numerous colleagues, most notably Michael Ayress, Richard Dingle, Caroline Maybury, Eugene Schornikov, Kerry Swanson and Mark Warne. The two referees, David Horne and Moriaki Yasuhara, are thanked for their various suggestions, but the authors remain responsible for the various conclusions arrived at in the paper. Funding for this study has also been partially financed from Grant UBACyT $20020110100170 \mathrm{BA}$. This paper is contribution number R-157 of the Instituto de Estudios Andinos 'Don Pablo Groeber' (IDEAN). Gerson Fauth thanks CNPq (The Brazilian Scientific and Technology Developing Council) for the gran (proc. 308544/2012-9). This paper is dedicated to the memory of Sara Ballent, who was the mentor of this project; may she rest in peace.

\section{Scientific editing by Alan Lord}

\section{References}

Aguirre-Urreta, B., Tunik, M., Naipauer, M., Pazos, P., Ottone, E., Fanning, M. \& Ramos, V.A. 2011. Malargüe Group (Maastrichtian-Danian) deposits in the Neuquén Andes, Argentina: Implications for the onset of the first Atlantic transgression related to Western Gondwana break-up. Gondwana Research, 19, 482-494.

Baird, W. 1850. The natural history of the British Entomostraca. Ray Society, London.

Ballent, S. \& Whatley, R. 2006. The Mesozoic ostracod genus Arculicythere Grekoff: Further evidence for the southern Gondwana seaway. Cretaceous Research, 27, 728-734

Ballent, S. \& Whatley, R. 2007. The distribution of the gondwanine ostracod Rostrocytheridea Dingle: Palaeozoogeographical implications. Geological Journal, 42, 113-125.

Bertels, A. 1973. Ostracodes of the type locality of the Lower Tertiary (Lower Danian) Rocanian Stage and Roca Formation of Argentina. Micropaleontology, 19, 308-340.

Bertels, A. 1974. Upper Cretaceous (lower Maastrichtian?) ostracodes from Argentina. Micropaleontology, 20, 385-397.

Blaszyk, J. 1987. Ostracods from the Oligocene Polonez Cove Formation of King George Island, West Antarctica. Palaeontologia Polonica, 49, 63-81.

Brandão, S.N. 2015. Cytheridae Baird, 1850. In: Brandão, S.N., Angel, M.V., Karanovic, I., Parker, A., Perrier, V., Sames, B. \& Yasuhara, M (eds) World Ostracoda Database. http://www.marinespecies.org/ostracoda/ retrieved 26 June 2015.

Briggs, M.W. 1978. Ostracoda from the Pleistocene Taylor Formation, Ross Island, and the Recent of the Ross Sea and McMundo Sound region, Antarctica. Antarctic Journal of the United States, 13, 27-29.

Ceolin, D., Whatley, R., Fauth, G. \& Concheyro, A. 2015. New genera and species of Ostracoda from the Maastrichtian and Danian of the Neuquén Basin, Argentina. Papers in Palaeontology, 1, 425-495.

Concheyro, A., Nañez, C. \& Casadío, S. 2002. El Límite Cretácico-Paleógeno em Trapalcó, província de Río Negro, Argentina: 'una localidad clave en América del Sur'. XV Congresso Geológico Argentino, El Calafate, Actas, 590-595.

Del Río, C.J., Concheyro, A. \& Martínez, S. 2011. The Maastrichtian-Danian at General Roca (Patagonia, Argentina): A reappraisal of the chronostratigraphy and biostratigraphy of a type locality. Neues Jahrbuch für Geologie und Paläontologie Abhandlungen, 259, 129-156.

Dingle, R.V. 2000. Ostracoda from CRP-1 and CRP-2/2A, Victoria Land Basin, Antarctica. Terra Antartica, 7, 479-492.

Dingle, R.V. \& Majoran, S. 2001. Palaeo-climatic and biogeographical implications of Oligocene Ostracoda from CRP-2/2A and CRP-3 drillholes, Victoria Land Basin, Antarctica. Terra Antarctica, 8, 369-382.

Hartmann, G. 1987. Antarktische benthische Ostracoden II. Auswertung der Fahrten der 'Polarstern' Ant. III/2 und der Reisen der 'Walther Herwig' 68/1 und 2. 2. Teil: Elephant Island und Bransfield Straße. Mitteilungen aus dem Hamburgischen zoologischen Museum und Institut, 84, 115-156.

Hartmann, G. 1988. Antarktische benthische Ostracoden III. Auswertung der Reise des FFS 'Walther Herwig' 68/1. 3. Teil: Süd-Orkney-Inseln. Mitteilungen aus dem Hamburgischen zoologischen Museum und Institut, 85, 141-162.

Hartmann, G. 1989a. Antarktische benthische Ostracoden IV. Auswertung der während der Reise von FFS 'Walther Herwig' (68/1) bei Süd-Georgien gesammelten Ostracoden. Mitteilungen aus dem Hamburgischen zoologischen Museum und Institut, 86, 209-230.

Hartmann, G. 1989b. Antarktische benthische Ostracoden V. Auswertung der Sudwinterreise von FS 'Polarstern' (Ps 9/V-1) im Bereich Elephant Island und der Antarktischen Halbinsel. Mitteilungen aus dem Hamburgischen zoologischen Museum und Institut, 86, 231-288.

Hartmann, G. 1990. Antarktische benthische Ostracoden VI. Auswertung der Reise der 'Polarstern' Ant. VI-2 (1. Teil, Meiofauna und Zehnerserien) sowie Versuch einer vorläufigen Auswertung aller bislang vorliegenden Daten). Mitteilungen aus dem Hamburgischen zoologischen Museum und Institut, 87, 191-245.

Hartmann, G. 1997. Antarktische und subantarktische Podocopa (Ostracoda). In: Wagele, J.W. \& Sieg, J. (eds) Synopses of the Antarctic Benthos, 7. Koeltz Scientific Books, Koenigstein, 355, 135-150.

Howell, A.J., Schwarz, E., Spalletti, A.L. \& Veiga, G.D. 2007. The Neuquén Basin: An overview. In: Veiga, G.D., Spalletti, A.L., Howell, A.J. \& Schwarz, E. (eds) The Neuquén Basin, Argentina. A Case Study in Sequence Stratigraphy and Basin Dynamics. Geological Society, London, Special Publications, 252, 1-14, http://doi.org/10.1144/GSL.SP.2005.252.01.01

Latreille, P.A. 1806. Histoire Naturelle. Generale et Particuliare des Crustaces et des Insectes, 4, 232-254.

Majewski, W. \& Olempska, E. 2005. Recent ostracods from Admiralty Bay, King George Island, West Antarctica. Polish Polar Research, 26, 13-36.

Milhau, B. 1993. Nouveaux ostracodes du Miocène inférieur de NouvelleZélande. Geobios, 26, 161-200.

Moore, R.C. \& Pitrat, C.W. 1961. Crustacea: Ostracoda. In: Moore, R.C. (ed.) Treatise on Invertebrate Paleontology, Part Q, Arthropoda 3. Geological Society of America, Boulder, CO, and University of Kansas Press, Lawrence Kansas, 465, 201-383.

Müller, G.W. 1894. Die Ostracoden des Golfes von Neapel und der angrenzenden Meeres-Abschnitte. Fauna und Flora des Golfes von Neapel und der Angrenzenden Meeres-Abschnitte Herausegeben von der Zoologischen Station zu Neapel, 21. R. Friedlander, Berlin.

Musso, T., Concheyro, A. \& Pettinari, G. 2012. Mineralogía de arcillas y nanofósiles calcáreos de las formaciones Jagüel y Roca em el sector oriental del Lago Pellegrini, Cuenca Neuquina, República Argentina. Andean Geology, 39, 511-540.

Piovesan, E.K., Ballent, S. \& Fauth, G. 2012. Cretaceous palaeogeography of southern Gondwana from the distribution of the marine ostracod Majungaella Grekoff: New data and review. Cretaceous Research, 37, 127-147.

Sars, G.O. 1866. Oversigt af Norges Marine Otracoder. Forhandlinger I Videnskabs-Selskabet I Cristiania, 1865, 1-130.

Uliana, M.A. \& Dellapé, D.A. 1981. Estratigrafia y evolucion paleoambiental de La sucesion Maestrichtiano-Eoterciaria Del Engolfamento Neuquino (Patagonia Septentrional). VII Congresso Geológico Argentino, San Luis, Actas iii, 673-711.

Whatley, R. \& Ballent, S. 1996. A review of the Mesozoic ostracod genus Progonocythere and its close allies. Palaeontology, 39, 919-939.

Yasuhara, M., Kato, M., Ikeya, N. \& Seto, K. 2007. Modern benthic ostracodes from Lützow-Holm Bay, East Antarctica: Paleoceanographic, paleobiogeographic, and evolutionary significance. Micropaleontology, 53, 469-496. 


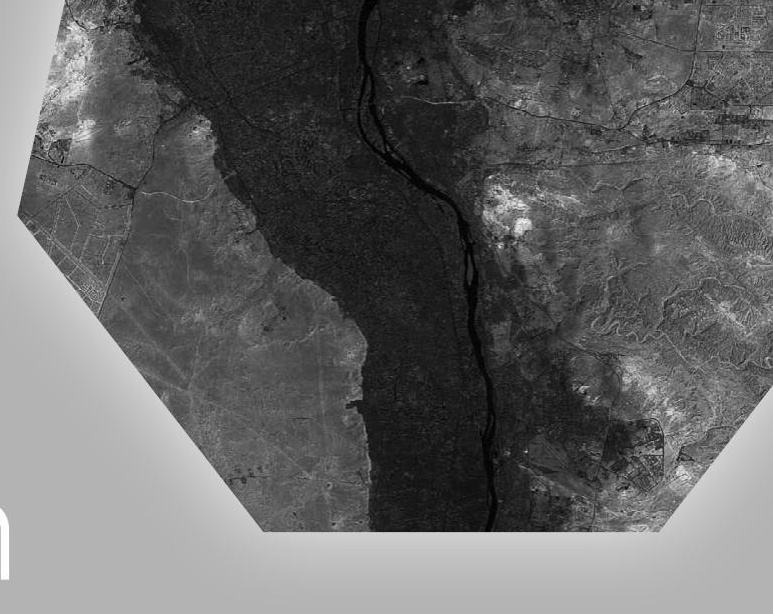

One of the largest integrated collections of online Earth science literature in the world
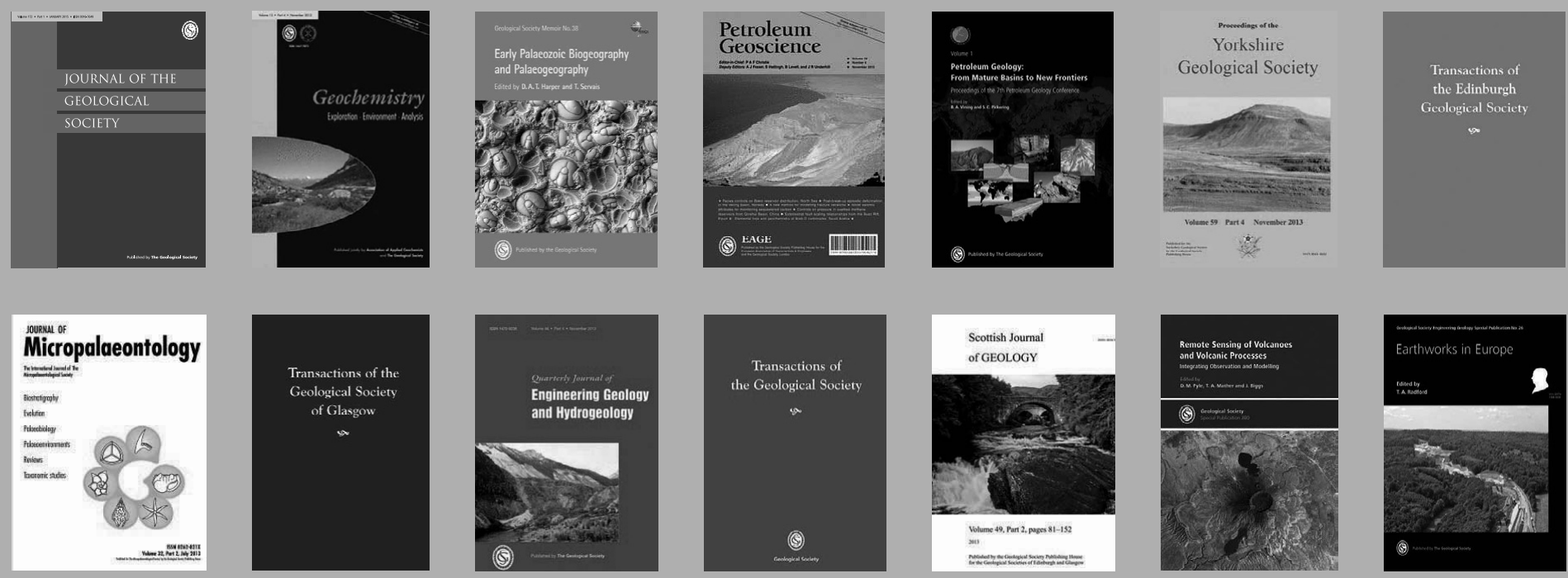

\section{What is the Lyell Collection?}

The Lyell Collection is an online collection comprising the Society's journal titles, Special Publications and key book series. Cutting edge science sits alongside important historical material, benefiting from the superb functionality offered by the online host, HighWire Press.

With 270,000 peer-reviewed pages, 26,000 articles and 1,000 volumes, the Lyell Collection is an invaluable tool for the researcher and student alike.

- Full text in HTML and PDF format

- Actively linking to cited references

- Free abstracts

- Free ETOC alerting

- Selected articles free online

- The Lyell Collection welcomes

Open Access papers
- JGS, QJ, GEEA and PG offer specially-designed sites for those using mobile devices

- Transactions of the Edinburgh Geological Society and

Transactions of the Geological Society of Glasgow

\section{Special Publication archives}

The first 300 volumes of the Geological Society's Special Publications Online Archive are available as a one-off purchase with perpetual access.

\section{The Geological Society}

The Geological Society of London was founded in 1807 and is the UK national society for geosciences. It is a global leader in Earth science publishing, dedicated to providing high-quality content and service throughout the world.

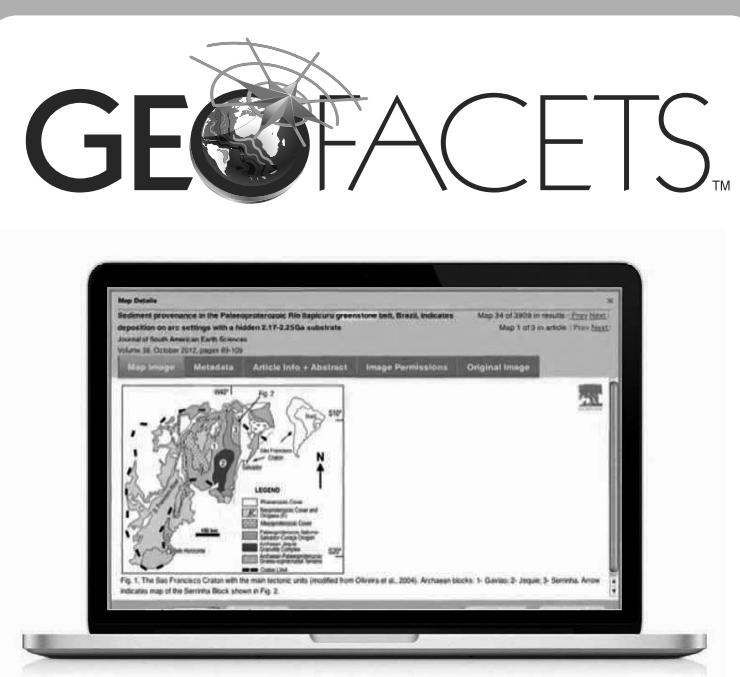

Geofacets-GSL Millennium Edition

Elsevier and the Geological Society of London (GSL) have collaborated to provide GSL members with a unique opportunity to gain individual access to $24,000+$ geological maps from the renowned Lyell Collection through the Geofacets platform.

The Geofacets platform is an innovative map-based research tool designed for geoscientists. These maps are downloadable, geo-referenced, and accompanied by metadata, article abstracts and links to original source articles. 